\title{
Parents' Perception on Mobile Phone Usage of Their Children and Knowledge on Its Hazards in Selected Hospital, Mangalore
}

\author{
Priya Sweety Pereira ${ }^{1, \odot ~ S o n i a ~ K a r e n ~ L i z ~ S e q u e r a ~}{ }^{1}$ \\ ${ }^{1}$ Department of Community Health Nursing, Father Muller College \\ of Nursing, Kankanady, Mangaluru, Karnataka, India
}

\begin{abstract}
Address for correspondence Priya Sweety Pereira, MSc, Department of Community Health Nursing, Father Muller College of Nursing, Father Muller Road, Kankanady, Mangaluru 575002, Karnataka, India (e-mail: prdsouza86@fathermuller.in).
\end{abstract}

\begin{abstract}
Keywords

- hazards of mobile phone usage

- knowledge

- parents

- perception

Introduction Cell phones have achieved a milestone in modern technology where they have become handy to everyone. Advancement taken place in mobile phone technology has enabled its use in online purchasing as well as communication. On one hand, it is a helping tool for faster communication; on other hand, we cannot deny the fact of its harmful effects. The young teens are the age group who have been addicted to the mobiles. It is only the parents who can mould child's behavior and personality. In this regard, parents can play an important role in enhancing the sense of responsibility in vigilant use of mobile at the early age.

Materials and Methods A quantitative descriptive research design was used in this study to collect data from 340 parents of 12 to 20 years age group who are visiting all the outpatient departments of selected Medical College Hospital, Mangaluru. Data was collected by administering demographic proforma, self-prepared perception checklist, and knowledge questionnaire on hazards of mobile phone usage.

Results Majority 230 (67.6\%) parents had generally perceived that their children were spending too much of time on mobile phone and also 187(55\%) parents perceived that children use mobile with earphones while traveling and 200(58.8\%) parents perceived that their children have become lazy and lost interest in studies too. A total of $210(61.8 \%)$ of parents had inadequate knowledge and $130(38.2 \%)$ of them had adequate knowledge on hazards of mobile usage. There was association between knowledge on hazards of mobile phone usage and selected demographic variables as the $p$-value computed was found to be significant at 0.05 level of significance. There was no association found between knowledge and gender (0.052).

Conclusion As per the study findings, it was very clear that parents were observing some of the behavioral and emotional changes that were happening in their children. Hence, parents need to be educated and made aware of the possible hazards of mobile usage that may help them to tackle all the childhood issues and help in child's overall development.
\end{abstract}

published online Jun 14, 2021
DOI https://doi.org/

$10.1055 / \mathrm{s}-0041-1731144$

ISSN 2582-4287
C 2021. Nitte (Deemed to be University).

This is an open access article published by Thieme under the terms of the Creative Commons Attribution-NonDerivative-NonCommercial-License, permitting copying and reproduction so long as the original work is given appropriate credit. Contents may not be used for commercial purposes, or adapted, remixed, transformed or built upon. (https://creativecommons.org/licenses/by-nc-nd/4.0/).

Thieme Medical and Scientific Publishers Pvt. Ltd. A-12, 2nd Floor, Sector 2, Noida-201301 UP, India 


\section{Introduction}

Advances in technology have made lives easier today. ${ }^{1}$ Everyone today, irrespective of any age group they belong to, are aware about these technologies and its uses. Advancement taken place in mobile phone technology has enabled its use in online purchasing as well as communication. ${ }^{2}$ It is difficult in today's world to live without mobile. Cell phones have achieved a milestone in modern technology where they have become handy to everyone and most of the works are done at one setting. ${ }^{3}$

On one hand, it is a helping tool for faster communication; on other hand, we cannot deny the fact of its harmful effects. ${ }^{2}$ To get connected with each other, the mobile phone uses radiations with frequency, which ranges from $3 \mathrm{kHz}$ to $300 \mathrm{GHz}$. And these radiations can contribute to many harmful diseases. Radiations can also cause headache, sleep disruption, tiredness, and DNA damage. ${ }^{4}$

The young teens are the age group who have been addicted to the mobiles. As cell phones are available at affordable price, the teens are addicted to it very easily. They depend completely on mobile phones and may experience behavioral issues and may also encounter with brain development problems. ${ }^{5}$ A study reveals that the teenagers are the most vulnerable group of mobile phone users who may utilize mobile for the good and bad purpose. It was found that among them the age group between 15 and 22 years is the one who were having more craze toward mobile phone. ${ }^{6}$

Parents play important role in upbringing of their children. Children may grow physically, mentally, and become an independent human being in society, but the role of parents has become much stronger. It's only the parents who can mould child's behavior and personality. So, parents should be vigilant to observe any deviation of child's normal behavior and help in motivating the children behavior and also in helping them to come out of difficulties they face. They can be a best teacher by observing their children by taking efforts to guide them. ${ }^{7}$

A cross-sectional analytical study was conducted aiming the impact of smart phone usage among 115 college students at Chennai between the age group of 17 to 25 years in December 2016. Results depicted that $74 \%$ of the participants were females, and 65\% were using smart phones for 3 to 5 years. Seventy-seven percent of the subjects were using it for more than 5 hours daily, $66 \%$ had habit of checking the smart phone while sleeping, and $72 \%$ of them used it for the educational purpose. Seventy-nine percent of students complained about headache, 51\% had anxiety, $47 \%$ had lack of concentration, $35 \%$ had sleeplessness, and $43 \%$ had neck and arm pain due to continued mobile usage. ${ }^{8}$

The above literature supports the fact that adolescents are more into the mobile usage and were certainly experiencing some health issues. The investigators have come across many young teens using the mobiles in college, while traveling and many other occasions with ignorance of immediate surroundings. Hence, there is a need to identify these issues and find out a way that can help in limited and cautious use of mobile. In this regard, parents can play an important role in enhancing the sense of responsibility in vigilant use of mobile at the early age.

\section{Materials and Methods}

Sample calculation formula:

$$
n=\frac{\boldsymbol{z} \dot{\boldsymbol{a}}^{2} \times \boldsymbol{p}(1-\boldsymbol{p})}{\boldsymbol{e}^{2}}
$$

Following values can be used for estimating the sample size $(p=0.67){ }^{9}$

$$
n_{0}=\frac{(1.96)^{2} \times 0.67(1-0.67)}{(0.05)^{2}}=339.75
$$

Total sample size $=340$.

\section{Methods}

A quantitative descriptive research design was used in this study to collect data from 340 parents of 12 to 20 years age group who are visiting all the outpatient departments of selected Medical College Hospital, Mangaluru. In this study, the children age group is considered between 12 and 20 years because review suggests that the above-mentioned age group is showing more addiction toward mobile phone.

Permission obtained from the Institutional Ethics Committee and the hospital authority. Using purposive sampling technique parents were selected and gathered in the outpatient department classroom. Investigators introduced themselves and voluntary informed consent was taken. Data was collected by administering demographic proforma, self-prepared perception checklist, and knowledge questionnaire on hazards of mobile phone usage. At the end of data collection, parents were thanked for their whole hearted cooperation. The collected data was kept confidential and coded for further analysis. The average time taken to complete the perception checklist and knowledge questionnaire was 10 to 20 minutes.

Pretesting and content validity was done by administering the tool to seven experts from different specialties of nursing field. The reliability of the tool for perception checklist and knowledge questionnaire was calculated using Cronbach's $\alpha$ with $r$ value 0.762 and 0.739 , respectively. Participants who scored more than $50 \%$ in the knowledge questionnaire were considered to have adequate knowledge and participants with score of $\leq 50 \%$ were considered to have inadequate knowledge. Parents' perception was depicted as frequency and percentage.

\section{Results}

The data were analyzed using SPSS version 16.

- Table 1 depicts that 187 (55\%) were female parents, 106 (31.2\%) had secondary school education, 209(61.5\%) belonged to nuclear family, and 131 (38.5\%) were self-employed. A total of 185 (54.4\%) parents heard information on hazards about mobile phone usage through mass media. A total of 139 (40.9\%) parents were using the mobile for $\leq 30$ minutes. 
Table 1 Percentage distribution of subjects according to their baseline characteristics, $n=340$

\begin{tabular}{|c|c|c|c|}
\hline S. no. & Variables & Frequency & $\%$ \\
\hline \multirow[t]{3}{*}{1.} & Gender & & \\
\hline & a. Male & 153 & 45.0 \\
\hline & b. Female & 187 & 55.0 \\
\hline \multirow[t]{6}{*}{2.} & Academic qualification & & \\
\hline & a. No formal education & 21 & 6.2 \\
\hline & $\begin{array}{l}\text { b. Primary school } \\
\text { education }\end{array}$ & 68 & 20.0 \\
\hline & $\begin{array}{l}\text { c. Secondary school } \\
\text { education }\end{array}$ & 106 & 31.2 \\
\hline & d. Preuniversity course & 78 & 22.9 \\
\hline & e. Graduation and above & 67 & 19.7 \\
\hline \multirow[t]{4}{*}{3.} & Type of family & & \\
\hline & a. Nuclear & 209 & 61.5 \\
\hline & b. Joint & 106 & 31.2 \\
\hline & c. Single parent family & 25 & 7.4 \\
\hline \multirow[t]{6}{*}{4.} & Occupation & & \\
\hline & a. Professional & 60 & 17.6 \\
\hline & b. Skilled & 72 & 21.2 \\
\hline & c. Unskilled & 56 & 16.5 \\
\hline & d. Self-employed & 131 & 38.5 \\
\hline & e. Unemployed & 21 & 6.2 \\
\hline \multirow[t]{6}{*}{5.} & $\begin{array}{l}\text { Knowledge on hazards of } \\
\text { mobile phone usage }\end{array}$ & & \\
\hline & a. No information & 37 & 10.9 \\
\hline & b. Mass media & 185 & 54.4 \\
\hline & c. Relatives/friends & 85 & 25.0 \\
\hline & d. Health workers & 33 & 9.7 \\
\hline & e. If any, mention & 0 & 0 \\
\hline \multirow[t]{4}{*}{6.} & $\begin{array}{l}\text { How much time do you spend } \\
\text { in mobile at home? }\end{array}$ & & \\
\hline & $\begin{array}{l}\text { a. Less than or equal to } 30 \\
\text { minutes }\end{array}$ & 139 & 40.9 \\
\hline & b. 30 minutes to 1 hour & 111 & 32.6 \\
\hline & c. More than 1 hour & 90 & 26.5 \\
\hline
\end{tabular}

The data in - Table 2 shows that majority of (230 [67.6\%] parents had generally perceived that their children are spending too much of time on mobile phone and also 187 (55\%) parents perceived that children use mobile with earphones while traveling and 200 (58.8\%) parents perceived that their children have become lazy and lost interest in studies too. On other hand, 181 (53.2\%) parents feel that mobile usage till late night is not observed in their children. One-hundred eighty (52.9\%) parents think that time spent to have their regular food is not affected due to phone use.
Also, it was noted that 185 (54.4\%) parents stated saying that their children use mobile only for school projects. Also, it was noted that 175 (51.5\%) parents perceived that their children are alert and responsive to commands, whereas 185 (54.4\%) parents observed that using mobile early in the morning for a long time is not observed. Also, 121 (35.6\%) parents observed that children use phone while the phone is plugged for charging.

The data in - Table $\mathbf{3}$ and -Fig. $\mathbf{1}$ depicts that majority $210(61.8 \%)$ of parents had inadequate knowledge and 130 (38.2\%) of them had adequate knowledge on hazards of mobile usage.

- Table 4 shows the overall mean percentage of knowledge score was $47.75 \%$ with mean and standard deviation of $3.82 \pm 2.02$. This suggests that the level of knowledge is not adequate or need to be improved.

$\mathbf{H}_{\mathbf{0}}$ : There will be no significant association between the knowledge on hazards of mobile phone usage and selected demographic variables.

The data presented in - Table 5 reveal that there is association between knowledge on hazards of mobile phone usage and selected demographic variables as the $p$-value computed between knowledge score on hazards of mobile usage and academic qualification (0.005), type of family (0.008), occupation (0.001), knowledge on hazards of mobile phone usage (0.010), and time spent on mobile at home (0.014) was found to be significant at 0.05 level of significance. There was no association found between knowledge and gender (0.052). Hence, null hypothesis rejected for all the variables, except for gender.

\section{Discussion}

Mobile phone usage is increasing nowadays in teen including children. Parents are aware about the fact, but are ignorant about the consequences what the children may face in the future. Here in the study, it shows that majority of parents had perceived about the ill effects of mobile, but the depth of knowledge was lacking. The knowledge of the parents also highlights about the lack of information on hazards of mobile usage.

Present study shows 187 (55\%) were female parents, 106 (31.2\%) had secondary school education at the time of data collection, whereas similar study findings shows that 164 (86\%) were female parents and 46 (24\%) had high school education. ${ }^{10}$ Family group of 209 parents was nuclear (61.5\%), while 131 (38.5\%) parents were self-employed. The total number of parents who heard about hazards of mobile phone usage through mass media were 185 (54.4\%). On the other hand, $139(40.9 \%)$ parents found that time duration spent by them on mobile phone use was $\leq 30$ minutes.

A similar study conducted at Coimbatore shows that among 30 adolescents, 17 (56.7\%) had inadequate knowledge, 13 (43.3\%) had moderate knowledge, and none had adequate knowledge on electronic gadgets. ${ }^{11}$ Whereas the present study results say that majority, 210 (61.8\%), of parents had inadequate knowledge and 130 (38.2\%) of them had adequate knowledge on hazards of mobile usage. 
Table 2 Percentage distribution of subjects according to their perception on mobile phone usage of their children, $n=340$

\begin{tabular}{|c|c|c|c|c|c|}
\hline \multirow[b]{2}{*}{ S. no. } & \multirow[b]{2}{*}{ Statements } & \multicolumn{2}{|c|}{ Yes } & \multicolumn{2}{|c|}{ No } \\
\hline & & $\mathrm{F}$ & $\%$ & $\mathrm{~F}$ & $\%$ \\
\hline 1. & I feel my child is spending too much time using cell phone & 230 & 67.6 & 110 & 32.4 \\
\hline 2. & My child uses mobile till late-night & 159 & 46.8 & 181 & 53.2 \\
\hline 3. & $\begin{array}{l}\text { My child takes long time to finish his food because of continuous } \\
\text { chatting in mobile }\end{array}$ & 160 & 47.1 & 180 & 52.9 \\
\hline 4. & $\begin{array}{l}\text { My child uses mobile phone only to complete the school/college } \\
\text { project and assignment. }\end{array}$ & 185 & 54.4 & 155 & 45.6 \\
\hline 5. & $\begin{array}{l}\text { Most of the time and also while traveling my child uses mobile } \\
\text { with the earphone }\end{array}$ & 187 & 55 & 153 & 45 \\
\hline 6. & $\begin{array}{l}\text { My child is so deep in use of mobile that he will not respond to } \\
\text { my commands }\end{array}$ & 165 & 48.5 & 175 & 51.5 \\
\hline 7. & $\begin{array}{l}\text { My child will not come out of bed in the morning unless uses } \\
\text { mobile at least for half an hour }\end{array}$ & 155 & 45.6 & 185 & 54.4 \\
\hline 8. & $\begin{array}{l}\text { My child is addicted to mobile to an extent where he/she uses it } \\
\text { with charging point on }\end{array}$ & 121 & 35.6 & 219 & 64.4 \\
\hline 9. & My child is become lazy because of continuous mobile usage & 200 & 58.8 & 140 & 41.2 \\
\hline 10. & After using mobile phone my child is lost interest in studies & 200 & 58.8 & 140 & 41.2 \\
\hline
\end{tabular}

Table 3 Distribution of subjects according to the level of knowledge, $n=340$

\begin{tabular}{|l|l|l|l|l|}
\hline Knowledge score & $\begin{array}{l}\text { Knowledge score } \\
\text { percentage }\end{array}$ & $\begin{array}{l}\text { Grading level of } \\
\text { knowledge }\end{array}$ & Frequency & Percentage \\
\hline $0-4$ & $0-50 \%$ & Inadequate & 210 & 61.8 \\
\hline $5-8$ & $51-100 \%$ & Adequate & 130 & 38.2 \\
\hline
\end{tabular}

Maximum score: 8.

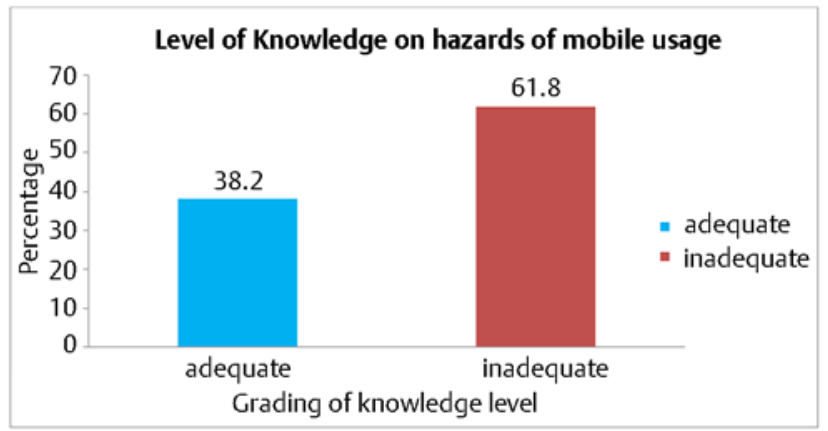

Fig. 1 Bar diagram showing the distribution of subjects according to the knowledge level.

The present study reveals that out of 340 parents, 230 (67.6\%) parents agree that their kids spend a lot of time using smart phone. At the same time 185 (54.45\%) parents say that the phone use is restricted only to complete their academic assignments. In this study, 159 (46.8\%) parents perceived that their children use mobile till late night, whereas 160 (47.1\%) agree that children will take long time to finish their food as they chat over the phone while having their lunch or dinner. One of the descriptive study findings show that $34.5 \%$ of parents (children age group: 6-12 years) who work at deemed university perceive that children show less interest while handling food. ${ }^{12}$ Also, 155 (45.6\%) parents say that early morning at least for half an hour their children use phone before they come out of their bed. The above findings suggest that these behaviors may have influence on child's health. Exposing to ear phone use while traveling was one of the perceptions that was observed by 187 parents (55\%). A similar study was conducted among 85 parents of preschool children (3-6 years) who opined that smart phone use may cause physical and mental problem specially making the child introvert and feel isolated and slowly withdraws child from society. Also, use of mobile phone exposes the child to harmful radiation. ${ }^{13}$

Use of mobile phone makes their children lazy that is affecting to lose their interest in studies was one of the perceptions identified by 200 (58.8) parents. Whereas a contradictory review says that learning and attention span has no significant difference with the phone usage $(r=0.07$, $p=0.47){ }^{14}$

There was significant association between knowledge on hazards of mobile phone usage and selected demographic variables: academic qualification $(p=0.005)$, type of family ( $p=0.008)$, occupation $(p=0.001)$, knowledge on hazards of mobile phone usage $(p=0.010)$, and time spent on mobile at home $(p=0.014)$.

\section{Conclusion}

Parents play a key role in upbringing of their children and they are the perfect people to mould them. As per the study findings, it is very clear that parents are observing some of the behavioral and emotional changes that are happening in their children. Many of the reviews say these changes may 
Table 4 Range, mean, standard deviation, and mean percentage of knowledge score, $n=340$

\begin{tabular}{|l|l|l|l|l|l|l|}
\hline Area & Item & Maximum score & Range & Mean \pm SD & Mean percentage & Level of knowledge \\
\hline $\begin{array}{l}\text { Total knowledge } \\
\text { score }\end{array}$ & 8 & 8 & 8 & $3.82 \pm 2.02$ & 47.75 & Inadequate \\
\hline
\end{tabular}

Abbreviation: SD, standard deviation.

Table 5 Association between knowledge and selected baseline variables, $n=340$

\begin{tabular}{|c|c|c|c|c|}
\hline S. no. & Variables & $<$ Median & $\geq$ Median & $p$-Value \\
\hline \multirow[t]{3}{*}{1} & Gender & & & \multirow[t]{3}{*}{0.052} \\
\hline & a. Male & 64 & 89 & \\
\hline & b. Female & 98 & 89 & \\
\hline \multirow[t]{6}{*}{2} & Academic qualification & & & \multirow[t]{6}{*}{$0.005^{\mathrm{a}}$} \\
\hline & a. No formal education & 15 & 6 & \\
\hline & b. Primary school education & 32 & 36 & \\
\hline & c. Secondary school education & 59 & 47 & \\
\hline & d. Preuniversity course & 35 & 43 & \\
\hline & e. Graduation and above & 21 & 46 & \\
\hline \multirow[t]{4}{*}{3} & Type of family & & & \multirow[t]{4}{*}{$0.008^{\mathrm{a}}$} \\
\hline & a. Nuclear & 86 & 123 & \\
\hline & b. Joint & 60 & 46 & \\
\hline & c. Single parent family & 16 & 9 & \\
\hline \multirow[t]{6}{*}{4} & Occupation & & & \multirow[t]{6}{*}{$0.001^{\mathrm{a}}$} \\
\hline & a. Professional & 24 & 36 & \\
\hline & b. Skilled & 34 & 38 & \\
\hline & c. Unskilled & 16 & 40 & \\
\hline & d. Self-employed & 79 & 52 & \\
\hline & e. Unemployed & 9 & 12 & \\
\hline \multirow[t]{5}{*}{5} & Knowledge on hazards of mobile phone usage & & & \multirow[t]{5}{*}{$0.010^{\mathrm{a}}$} \\
\hline & a. No information & 22 & 15 & \\
\hline & b. Mass media & 73 & 112 & \\
\hline & c. Relatives/friends & 47 & 38 & \\
\hline & $\begin{array}{l}\text { d. Health workers } \\
\text { If any, mention }\end{array}$ & 20 & 13 & \\
\hline \multirow[t]{4}{*}{6} & $\begin{array}{l}\text { How much time do you spend in mobile at } \\
\text { home? }\end{array}$ & & & \multirow[t]{4}{*}{$0.014^{\mathrm{a}}$} \\
\hline & a. Less than or equal to 30 minutes & 73 & 66 & \\
\hline & b. 30 minutes to 1 hour & 58 & 53 & \\
\hline & c. More than 1 hour & 31 & 59 & \\
\hline
\end{tabular}

Note: $p<0.05$.

aSignificant.

have an effect on physical, emotional, behavioral, and cognitive level of a child. Hence, parents need to be educated and made aware of the possible hazards of mobile usage that may help them to tackle all the childhood issues and help in child's overall development.

\section{Funding}

This work was supported by Father Muller Research Center research grant.

\section{Conflict of Interest}

None declared.

\section{Acknowledgments}

The authors would like to acknowledge the support of the Principal, Father Muller College of Nursing. The authors also thank the Director, FMCI and Administrator, FMMCH, for permitting for data collection. Also, we thank Father Muller Research Center for sanctioning the grant to 
conduct the study. We thank the experts for their guidance and also participants of the study for their whole-hearted participation.

\section{References}

1 Anonymous. Technology in Our Life Today and How It Has Changed. AgingInPlace.org. Published September 24, 2018. Updated for 2020. https://aginginplace.org/technology-in-ourlife-today-and-how-it-has-changed/. Accessed May 19, 2021

2 Veluri S. Technology in Today's World. Lets Nurture An IT Company Nurturing Ideas into Reality. Published December 5, 2016. https://www.letsnurture.com/blog/technology-todays-world.html. Accessed May 19, 2021

3 Kingston K. The Importance of Cell Phones in Modern Society. Streetdirectory.com. https://www.streetdirectory.com/travel_ guide/153893/cell_phones/the_importance_of_cell_phones_ in_modern_society.html. Accessed May 19, 2021

4 Suhag AK, Larik RSA, Mangi GZ, Khan M, Abbasi SK, Madiha H. Impact of excessive mobile phone usage on human. J Comput Sci Syst Biol 2016;09(6):173-17710.4172/jcsb.1000235

5 Anonymous. Cell Phone Addiction. PsychGuides.com.. https:// www.psychguides.com/behavioral-disorders/cell-phone-addiction/. Accessed May 19, 2021

6 Ball I. Mobile Phone and Teenagers. Streetdirectory.com.. https://www.streetdirectory.com/travel_guide/117157/ cell_phones/mobile_phone_and_teenagers.html. Accessed May 19, 2021
7 Anonymous. Importance of Parents in Life| Roles and actions. Cuemath. https://www.cuemath.com/learn/importance-of-parents/. Accessed May 19, 2021

8 Subramanian SS, Sindhuja RM. Impact of smart phone usage among college students - an analytical study. Int J Sci Res 2017;6(9):588-590 https://www.ijsr. net/archive/v6i9/ART20176642.pdf (IJSR)

9 Pendse N, Zagade T. Knowledge and attitude regarding health hazards of mobile phone users among the junior college students. Int J Sci Res 2014;3(5):554-561 https://www.ijsr. net/archive/v3i5/MDIwMTMxODU2.pdf (IJSR)

10 McCloskey M, Johnson SL, Benz C, et al. Parent perceptions of mobile device use among preschool-aged children in rural head start centers. J Nutr Educ Behav 2018;50(1):83-89.e1

11 Valarmathy A. A comparative study to evaluate the effectiveness of video assisted teaching versus playway approach on the knowledge regarding the hazards of electronic gadgets among early adolescents in selected schools, Coimbatore. - EPrints@ Tamil Nadu Dr MGR Medical University. Published online October 2017. http://repository-tnmgrmu.ac.in/10066/. Accessed May 19, 2021

12 Devamani S, Paul H, George J, Begum S, Dsouza SN, Lobo MR. Parent's perception regarding mobile phone usage led behaviour changes in children. Current Pediatric Research 2019;23(4):143-147

13 Genc Z. Parents' perceptions about the mobile technology use of preschool aged children. Procedia Soc Behav Sci 2014; 146:55-60

14 Tanil CT, Yong MH. Mobile phones: the effect of its presence on learning and memory. PLoS One 2020;15(8):e0219233 